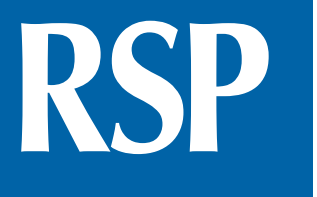

http://www.rsp.fsp.usp.br/
Revista de Saúde Pública

\title{
Scoping review of studies on food marketing in Latin America: Summary of existing evidence and research gaps
}

\author{
Maria Manuela Chemas-Velez' iD, Luis F. Gómez' iD, Alcides Velasqueziv ${ }^{\text {ID }}$, Mercedes \\ Mora-Plazas" iD, Diana C. Parra"l' iD \\ I Pontificia Universidad Javeriana. Facultad de Medicina. Departamento de Medicina Preventiva y Social. \\ Bogotá, Colombia. \\ " Universidad Nacional de Colombia. Facultad de Medicina. Departamento de Nutrición Humana. \\ Bogotá, Colombia. \\ III Washington University in St. Louis. School of Medicine. Program of Physical Therapy. St. Louis, USA. \\ Iv University of Kansas. Department of Communication Studies. Lawrence, KS, USA.
}

\author{
Correspondence: \\ Maria Manuela Chemas-Velez \\ Carrera 7 \#40-62 \\ Hospital Universitario San Ignacio, \\ 8 piso \\ Facultad de Medicina \\ Pontificia Universidad Javeriana \\ 110231 \\ Bogotá, CO \\ E-mail: mchemas@javeriana.edu.co
}

Received: Sep 3, 2018

Approved: May 9, 2019

How to cite: Chemas-Velez MM, Gomez LF, Velasquez A Mora PLazas MM, Parra DC. Scoping review of studies on food marketing in Latin America: Summary of existing evidence and research gaps. Rev Saude Publica. 2018:53:107.

Copyright: This is an open-access article distributed under the terms of the Creative Commons Attribution License, which permits unrestricted use, distribution, and reproduction in any medium, provided that the original author and source are credited.

\section{ABSTRACT}

OBJECTIVE: To document the evidence about marketing of ultra-processed foods and "non-alcoholic" beverages in Latin America.

METHODS: We performed a structured search of quantitative and qualitative studies in PubMed, SciELO and LILACS, published between January 2000 and May 2017 and conducted in Latin America. We conducted a quality assessment following a standardized tool and a thematic analysis to identify key typologies of marketing across studies

RESULTS: Out of 521 studies screened by title and abstract, we included 36 in this review; 27 of them analyzed television advertisement. Other marketing channels studied were food packaging, point of sale and outdoor advertisement. Studies found television advertises foods and beverages that are mostly ultraprocessed foods and have low nutritional value, particularly those promoted during children's programming. We also observed children have a literal interpretation of images printed on food packaging, so this can be deceiving. Several studies also found proximity to unhealthy foods may increase their consumption. Finally, the thematic analysis identified the following typologies of food marketing: a) television advertisement, b) food packaging marketing, c) marketing strategies at points of sale and d) other marketing strategies. We found almost no advertisements for unprocessed or minimally processed foods such as fruits and vegetables. We did not find any studies on digital marketing conducted in the region.

CONCLUSIONS: This review found that the main channel of food marketing was television advertising. This synthesis provides insights to the challenges unhealthy eating represents to the public health of Latin America and identifies knowledge gaps to guide future research. 


\section{INTRODUCTION}

According to the Global Burden of Disease Study, unhealthy dietary patterns have become the third risk factor associated with disability-adjusted life years and the second risk factor associated with mortality in Latin America and Caribbean ${ }^{1}$. Evidence shows the consumption of ultra-processed foods, including sweetened beverages, is associated with obesity and type 2 diabetes ${ }^{2-4}$. Changes in eating patterns and the growing consumption of ultra-processed foods and beverages ${ }^{5-7}$ characterize Latin America's rapid nutrition transition For instance, a study conducted in Brazil showed an increase of $4.8 \%$ in the energy value of ultra-processed foods between 2002-2003 and 2008-2009 ${ }^{6}$. Another Mexican study found the calories from beverages frequently marketed to children increased from $161 \mathrm{kcal}$ in 1999 to $310 \mathrm{kcal}$ in $2006^{7}$.

Marketing plays an important role in this transition process as it allows to modify and reinforce social norms that dictate the type of foods to be eaten and the manner and time to eat them. Marketing often depicts foods being consumed in situations other than mealtimes, away from the table and in unlimited quantities ${ }^{8,9}$. The food and beverage industries spend billions of dollars every year on advertising ${ }^{10}$, and the vast majority of promoted products are energy-dense and nutrient-poor ${ }^{11-16}$.

Children are extremely vulnerable to food marketing. They are highly impressionable, cannot recognize advertising intent, lack nutritional knowledge, and are motivated by immediate gratifications. ${ }^{12,15,16}$. Moreover, food companies target children for they have a strong influence in what families buy and establish brand loyalty at an early age, which has long-term effects on eating preferences and behaviors., ${ }^{911,16}$. For example, the risk of becoming an overweight adult is twice as much for an overweight child compared with a normal weight child ${ }^{17}$.

Several studies on food and beverage marketing have been conducted in Latin America; however, no recent syntheses summarize the main results from the available literature. Therefore, we performed a scoping review ${ }^{19}$ of studies that analyzed marketing of food and nonalcoholic beverages conducted in Latin America, in terms of exposure, marketing strategy, and nutritional value, using both qualitative and quantitative methods.

\section{METHODS}

We conducted a scoping review following the Joanna Briggs Institute guidelines ${ }^{18}$, which is the criteria recommended by Colquhoun et al. ${ }^{19}$ and used PRISMA guidelines to design the protocol and report the results ${ }^{20}$. We documented the study objectives, methods, inclusion criteria and quality assessment in a study protocol. This form of knowledge synthesis enabled systematically searching, selecting, and synthesizing the existing evidence in this area of study $^{19}$. The research questions were: What is the evidence regarding the marketing of food and nonalcoholic beverages conducted in Latin America? And, what are the key typologies of marketing across studies?

\section{Data Sources and Search Strategy}

We took the evidence documented in this scoping review from original quantitative and qualitative studies in the area of food and beverage marketing, which were conducted in Latin and Central American countries and the Greater Antilles (Cuba, Hispaniola; Haiti and the Dominican Republic, Puerto Rico and Jamaica). In this review, marketing was assumed as "any form of commercial communication or message that is designed to, or has the effect of, increasee the recognition, appeal and/or consumption of particular products and services. It comprises anything that acts to advertise or otherwise promote a product or service" (WHO, p. 9)

After clearly identifying the research question, scoping reviews need to identify relevant studies. To ensure the comprehensiveness and range of our search, we investigated studies 
in the following electronic databases: PubMed, SciELO and LILACS. To further ensure the desired level of breadth, we included studies published in Spanish, Portuguese, French and English. The time frame of publication was from January 2000 to May 2017. The search included the following free terms, using the Boolean operator "OR": "marketing", "advertisement", "publicity", "promotion", and "ad”. Moreover, the terms "food" and "beverage" were added to the query using the operator "AND" (Appendix I). This search strategy was defined to support sensitivity and reduce the risk of omitting relevant studies. In addition, we conducted a manual search to include relevant articles cited in the studies found, following recommendations of scoping reviews experts ${ }^{19}$. Finally, we contacted Latin American researchers and public health advocates members of the Coalición Latinoamérica Saludable (Healthy Latin America Coalition), to verify gray literature sources. We carried out the search until May 31, 2017.

\section{Study Selection and Inclusion Criteria}

Two of the authors undertook the study selection process, which can be seen in the PRISMA flow diagram (Figure 1) based on the content of titles and abstracts and in a second step based on the review of the manuscript text. In case of discrepancies, a third author reviewed the manuscript, and an agreement was obtained using a deliberative process. Studies that were not directly connected with health, nutrition and or food marketing were not included in this review.

\section{Data Extraction and Quality Assessment}

For each study inclusion, two authors independently extracted the data, based on titles and abstracts. Subsequently, these two reviewers extracted the basic information from
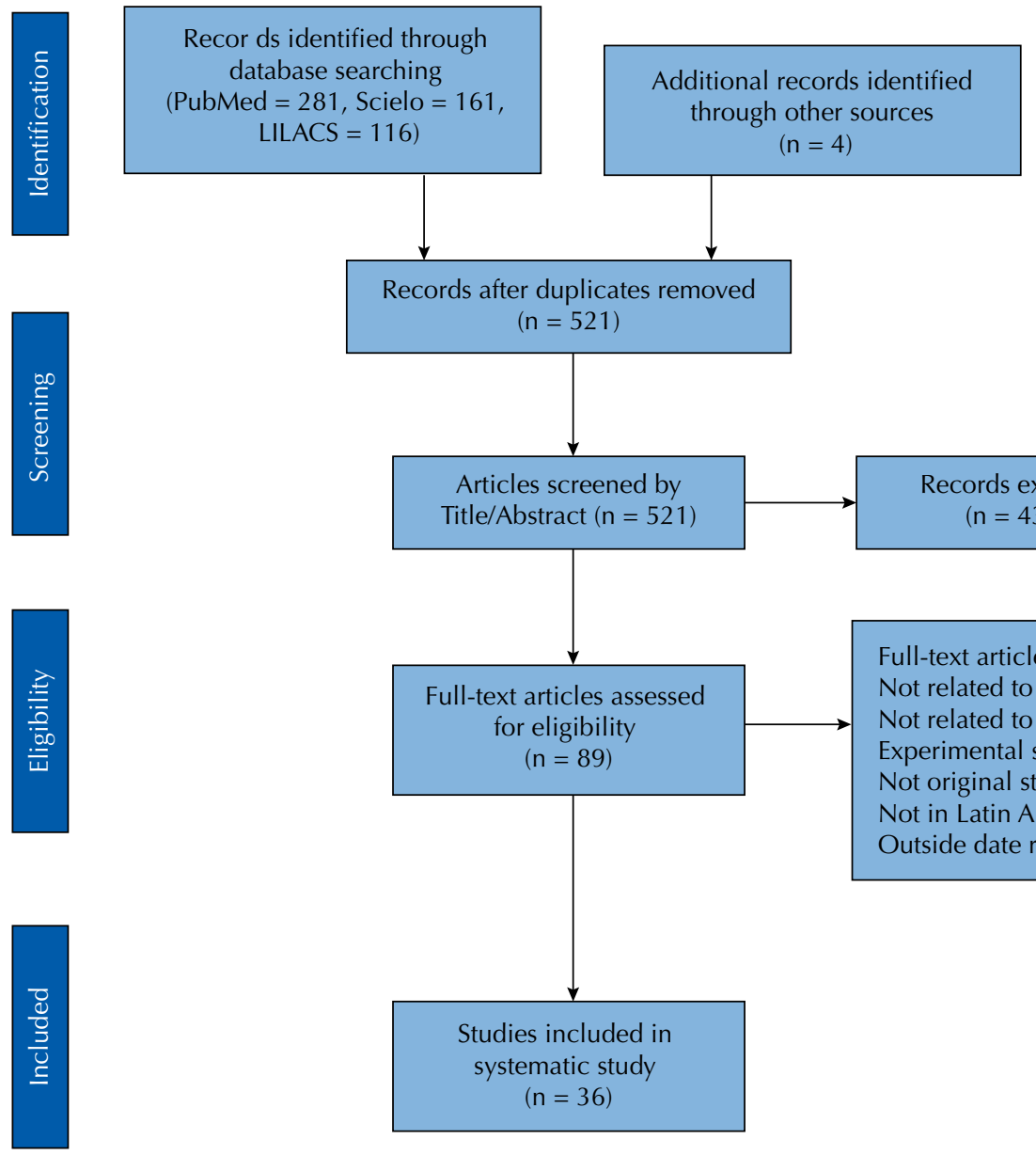

Records excluded $(n=432)$

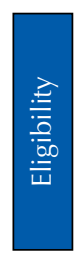

Full-text articles excluded: Not related to marketing $(n=18)$ Not related to health $(n=8)$ Experimental setting $(n=5)$ Not original study $(n=15)$ Not in Latin America $(n=3)$ Outside date range $(n=4)$ 
the manuscript texts and assessed the quality of each study. In case of disagreement, a third author was consulted. The following information was obtained and summarized from each study: authors, publication date, country, year in which the study was conducted, study design and objectives, study population, sample size, prevalence, and sociodemographic correlates.

A quality assessment was performed on both quantitative and qualitative articles following a standardized tool that has been used by authors in similar situations and that enables the application to several research methods ${ }^{22}$. Five items were assessed: a) Is there a clear and focused research question? b) Did the authors establish a theoretical framework? c) Was the methodology used appropriate for the objectives of the study? d) Did the authors recognize and describe the limitations of their study? and e) Did the authors clearly describe their results? The studies were classified for each of these criteria as "meeting the criteria"; 20 points, "partially meeting the criteria"; 10 points, and "not meeting the criteria"; 0 points. Finally, a percentage of criteria met were calculated and studies were labeled as being of poor quality $(<60 \%)$, fair quality $(60 \%-90 \%)$, and good quality (> 90\%).

\section{Analytical Approach}

Two methods of analysis were used. Firstly, we briefly described the objective, study design, setting and main results of the studies. The second was a thematic analysis that was used to identify key typologies of marketing across studies ${ }^{23}$. The authors reviewed, refined and named these typologies during several meetings, considering the terminology proposed by the World Health Organization ${ }^{22}$. Since some studies addressed several topics of marketing, their findings might be included in several typologies.

\section{RESULTS}

We identified 558 studies in our database search in PubMed, Scielo and LILACS and four additional studies were found by a manual search of cited articles and by contact with public health researchers, for a total of 562 studies. After adjusting for duplicates, 521 studies remained. Out of these, 432 were discarded based on title and abstract and 89 studies were selected for full text assessment. Among these, 53 articles did not meet the inclusion criteria and were discarded; 36 studies were included (Figure 1).

The Table 1 shows a general description of the main characteristics and findings of the 36 studies included in the review ${ }^{24-59}$. Ten studies were conducted in Brazil, eight in México, and five in Guatemala. The other studies were from Peru $(\mathrm{n}=4)$, Argentina $(\mathrm{n}=3)$, Chile $(\mathrm{n}=3)$, Honduras $(\mathrm{n}=1)$, El Salvador $(\mathrm{n}=1)$, and Colombia $(\mathrm{n}=1)$. In total, 27 studies were quantitative, six were qualitative and three used mixed method approaches.

Appendix II shows the results of the quality assessment, in which zero studies were judged as being poor quality, 21 had fair quality and 16 had good quality.

The thematic analysis identified the following typologies: a) television advertisement, b) food packaging marketing, c) marketing strategies at points of sale and d) other marketing strategies. Figure 2 shows the main findings of the review based on these typologies.

Twenty-five studies inquired several topics related with television advertisement. Fourteen of them found that food and nonalcoholic beverage advertisements represented between $5.6 \%$ and $36.4 \%$ of all television ads ${ }^{24,27-29,34,36,37,40,43,49,52,53,56,59}$.

Seventeen studies found the most frequently advertised food products were ultra-processed foods, whereas almost no advertisements were found for unprocessed foods such as fruits and vegetables s, $27,29,31,34,36-38,40,43,49,52,53,56,57,59,60^{2}$ 
Table 1. Studies conducted in Latin-American countries about food marketing and health.

\begin{tabular}{|c|c|c|c|}
\hline $\begin{array}{l}\text { Author } \\
\text { and year of } \\
\text { publication }\end{array}$ & $\begin{array}{l}\text { Country } \\
\text { and year of } \\
\text { study }\end{array}$ & Study design and objective & Setting \\
\hline $\begin{array}{l}\text { Sousa et al. }{ }^{24} \\
(2002)\end{array}$ & $\begin{array}{c}\text { Brazil, } \\
\text { 1998-2000 }\end{array}$ & $\begin{array}{c}\text { Quantitative study } \\
\text { (cross-sectional). } \\
\text { To analyze the quantity and } \\
\text { quality of food advertised } \\
\text { on the three main broadcast } \\
\text { channels in Brazil }\end{array}$ & $\begin{array}{l}\text { Three main broadcast } \\
\text { channels were recorded } \\
\text { during different times of } \\
\text { the day on weekdays and } \\
\text { Saturdays. }\end{array}$ \\
\hline $\begin{array}{l}\text { Olivares } \\
\text { et al. } .^{25}(2003)\end{array}$ & $\begin{array}{l}\text { Chile, } \\
2000\end{array}$ & $\begin{array}{c}\text { Quantitative study } \\
\text { (cross-sectional). } \\
\text { To determine attitudes } \\
\text { towards television } \\
\text { food advertising and } \\
\text { eating behaviors among } \\
\text { schoolchildren in different } \\
\text { municipalities. }\end{array}$ & $\begin{array}{c}\text { The researchers interviewed } \\
271 \text { schoolchildren (5th to } 8 \text { th } \\
\text { grade) from } 3 \text { different Chilean } \\
\text { cities. }\end{array}$ \\
\hline
\end{tabular}

Food products were the most frequently advertised product with $27.4 \%$. The category that appeared

Almost all children (92\%) reported watching television daily. When asked about television food commercials, $69.7 \%$ said they enjoyed them and $88.7 \%$ could remember at least one that they liked.

Most of the participants had a positive perception regarding the consumption of fruits and vegetables. Most also reported liking snack food and buying these products with their own money. Frequent intake of snack foods was not a habit for most students. Most of the students reported watching television daily.

Food-related advertisements accounted for $22 \%$ of recorded commercials. Among these, 50\% were

child-oriented. The most frequently advertised foods were potato and corn chips (97\%), desserts and cakes $(89 \%)$, juices $(77 \%)$ and sweetened

cereals $(75 \%)$. High-energy dense foods were disproportionately advertised to children $(60 \%)$ when compared with those to adults $(40 \%)$. Only $1 \%$ of all food advertisements promoted vegetables and fruits.

Food products composed $17.6 \%$ of advertisements. Children programs had more advertisements when compared with general audience programs $(19.89 \%$ vs. $15.46 \%)$, more food advertisements

( $25.8 \%$ vs. $15.4 \%)$ and higher frequency of advertisements for sweetened beverages ( $34.5 \%$ vs. $26.3 \%)$, and sweetened cereals ( $29.1 \%$ vs. $13.7 \%$ ).

Recordings were made of seven public access channels in Chile and advertisements were extracted and analyzed according to their frequency and duration. The foods advertised were classified as healthy, moderately healthy, and unhealthy based on the "Traffic Light System" by the UK Food Standard Agency.

A total of $16 \%$ of ads were identified as food advertisements. From these, $64 \%$ were related to unhealthy food, $27 \%$ to moderately healthy food and $9 \%$ to healthy food. The most frequently advertised food product was soft drinks (20\%).
Olivares et al. ${ }^{30}$ Chile, (2011)
Chile, 2010 hat

Association and to describe food products advertised.
Quantitative study (cross-sectional). To determine the attitude of Chilean school children from different socioeconomic levels and different regions of the country towards marketing of foods and beverages.
Children from three different cities in Chile and from different socioeconomic status were selected. A previously validated questionnaire was used. most often was fats, oils, sugars, and sweets

$(57.8 \%)$, followed by breads, cereals, rice, and pasta $(21.2 \%)$, dairy products $(11.7 \%)$, and lastly meat, eggs, and legumes (9.3\%).

Fair quality

Between $26 \%$ and $66 \%$ of children reported

liking food advertisements on television. In upper middle-income children, the percentage was similar between all three regions of the country (26\% in Santiago, 29\% in Chillán and 35\%

in Arica). In lower middle-income children, a marked increase was observed in Santiago, where $66 \%$ reported liking television foods commercials compared with $34 \%$ in Chillan and $26 \%$ in

Arica. When researchers asked children if they remembered food commercials that they liked $66 \%$ said they did and $65 \%$ reported interest in trying new foods advertised by this medium. The food and beverage commercials that the children preferred were: sweetened beverages, fruit juices, chocolates, ice cream, breakfast cereals and potato chips. 
Table 1. Studies conducted in Latin-American countries about food marketing and health. Continuation

\begin{tabular}{ccc}
\hline $\begin{array}{c}\text { Quantitative study } \\
\text { (cross-sectional). }\end{array}$ \\
$\begin{array}{l}\text { Tontos et al. }{ }^{31} \quad \text { Brazil, } \\
(2012)\end{array} \quad 2008 \quad \begin{array}{c}\text { and nutritional value of } \\
\text { food items promoted on } \\
\text { the Brazilian free-to-air } \\
\text { television. }\end{array}$ \\
\end{tabular}

Qualitative study. To compare eating habits

Rodrigues et $\mathrm{al}^{32}$ (2012)

Brazil, and consumer behaviors 2006 and of children from different 2008 socioeconomic levels and to investigate their relation to television watching habits.

\section{Quantitative study} (cross-sectional). To analyze the potential Costa et al. ${ }^{33} \quad$ Brazil, influence of food television (2012) 2009 advertising on the eating behavior and nutritional status of children and adolescents.

\section{Quantitative study} (cross-sectional).

To determine the frequency of food advertisements on television targeting adults aired on two public access Bacardí-Gascón Mexico, television channels and et al. ${ }^{34}$ (2013) 2011 to explore the relation between foods advertised, foods consumed by mothers and children and the anthropometric data of both.

\begin{tabular}{|c|c|c|}
\hline $\begin{array}{l}\text { Chacon et al. } \\
\text { (2013) }\end{array}$ & $\begin{array}{c}\text { Guatemala, } \\
\text { no year } \\
\text { information. }\end{array}$ & $\begin{array}{c}\text { Quantitative study } \\
\text { (cross-sectional). } \\
\text { To determine the } \\
\text { availability of snacks } \\
\text { that have child-oriented } \\
\text { marketing strategies on the } \\
\text { labels inside school stores } \\
\text { and in stores surrounding } \\
\text { schools; to assess their } \\
\text { nutritional quality. }\end{array}$ \\
\hline
\end{tabular}

Díaz-Ramírez Mexico, et al. ${ }^{36}$ (2013) 2011 (2013)
Costa et al. ${ }^{37}$
Quantitative study (cross-sectional). To assess the frequency of food advertising broadcasted on

2 free-access television channels and to explore the associations between food advertisements and the eating patterns of mothers and their children.

Quantitative study (cross-sectional). To conduct a content analysis of television food advertising on broadcast channels during children's programming hours
Two public access channels with the highest ratings in Brazil were recorded during two nonconsecutive weeks.

Food advertisements were classified according to the food pyramid and nutritional values were obtained from the packaging.

Twenty-three focus groups were conducted in 111 students between 7 and 10 years old from private and public schools. The households of private school students had higher income than those of public school students.

A total of 116 students between 7 and 15 years old were selected to answer self-administered and selfexplanatory questionnaires.

Two public access national television channels with the highest ratings were recorded during peak audience hours for a 5-month period. Women with children under 6 years of age from two states were recruited at educational and health facilities. They were asked to respond a self-administered questionnaire, attend an interview, and had their and their children's weight and height measured.

The availability of child-oriented snacks was assessed in stores inside schools and within a 200 square meters perimeter of 4 public schools in Mixco Guatemala. Nutritional quality was established following the UK Food Agency standards.

Two free-access television channels with the highest ratings were recorded during weekdays at peak hours. A total of 365 mothers of children between 8 months to 5 years old and their children were interviewed to explore the type of foods consumed. The nutritional composition was assessed using the Mexican Health Bureau standards and the UK Food Agency standards.

Three public channels were recorded during weekdays and weekends. The categorization of foods was based on the Dietary Guidelines for the Brazilian Population.
Out of the food items, advertised $85 \%$ were sugars, oils, or fats. No advertisements were found for fruits or vegetables.

Most children had pocket money they could spend. Most reported liking and watching television daily. Most children said they liked and wished to buy food products advertised on television.

All children reported watching television daily. When asked about food advertisements on television, $46.9 \%$ reported liking and buying advertised food items and $54.9 \%$ said they were attracted to new products advertised through this medium. In addition, the study found a positive relation between the number of hours spent watching television and body weight.

A positive association was found between the frequency of television advertising and the weekly consumption of the foods advertised. A positive association was also found between hours spent by children watching TV and their BMI-Z scores.
A total of 106 packages in 55 stores were analyzed. Savory snacks were the most commonly found child-oriented edible products. The most characters $(92.5 \%)$. Nutrition-related health claims were found in $41 \%$ of packages on child-oriented snacks. Most (97.1\%) of the child-oriented snacks were classified as "less-healthy". frequent marketing technique used was licensed
Good quality
Food products composed $25 \%$ of advertisements. Due to high levels of fat (25\%), sugar (34\%) and sodium $(42 \%), 67 \%$ of them were classified as unhealthy.

A positive correlation was observed between the food advertisements that mothers recalled and the frequency of advertisement. A positive correlation was found between the frequency of the foods advertised and their consumption by the mothers and their children.

Food advertisements represented $13.8 \%$ of all advertisements. The most frequent foods advertised were sugars and candies $(48.1 \%)$ and oils, fats and oleaginous seeds (29.1\%). By comparison only $1.1 \%$ of food advertisements promoted the 
Table 1. Studies conducted in Latin-American countries about food marketing and health. Continuation

Quantitative study To study the influence of Rojas-Huayllani et al. $^{38}(2013)$ Perú, 2010 on the consumption elementary school children.

Busse et $\mathrm{al}^{39}$ (2014)

Perú, 2012 viewing patterns and eating habits among elementary school children.

Quantitative study (cross-sectional).

To study the nutritional quality of foods and

Gunderson Honduras, beverages advertised during et $\mathrm{al}^{40}(2014) \quad 2012 \quad$ children's programming in Honduras and to describe the percentage of advertisements targeting children.

Qualitative study. To determine the food products most frequently Letona et $\mathrm{al}^{41}$ Guatemala, purchased by children, (2014) 2013 the reasons behind these choices and how children judge the nutritional value of food products. (cross-sectional). television advertisements of unhealthy foods in questionnaire regarding television viewing habits. The most popular television shows were recorded and the food items advertised were presented to children in a second survey to determine whether they recognized the products and had consumed them.

Data were collected from surveys, focus groups and indepth interviews with children between 6 and 11 years of age and their parents.

Four television stations were chosen; one public broadcast station and three cable stations.

They were recorded and television commercials were coded and analyzed. Advertised foods were categorized as on the classification scheme developed by Ramirez-Ley et al.

Children between the ages of 7 and 12 years from two public elementary schools in Mixco, Guatemala, entered in focus groups where they participated in three separate activities: list making, picture selection and a drawing exercise.

Qualitative study. To analyze how children Mazzonetto Brazil, perceive their role in food et $\mathrm{al}^{42}$ (2014) $2014 \quad$ purchases made by parents and the motivation behind their food preferences.
Children responded a healthy and unhealthy, based
Focus groups were used to examine these topics with children between the ages of 8 and 10 years old that attend public schools in Florianópolis, Brazil.
From the students surveyed, $100 \%$ reported watching television for at least 3 hours every

day. The foods advertised the most were cookies $(31.5 \%)$, sweetened beverages (30.4\%), chocolates $(17.3 \%)$, and candies $(9.2 \%)$. The

Quantitative study (cross-sectional).

To describe the nutritional Mejía-Díaz Colombia, $\begin{gathered}\text { profile of foods and } \\ \text { nonalcoholic beverages }\end{gathered}$ et $\mathrm{al}^{43}$ (2014) 2012 advertised on television by type of audience (children's programming vs. general programming).

Recording the two public access channels with the highest rating in Colombia, on weekdays and weekends. The foods were classified according to UK Food Standards Agency, WHO standards and Colombian micronutrient standards.

\section{A photographic}

Qualitative study. To explore how highly processed foods and beverages are promoted in Amanzadeh El Salvador, outdoor advertising in terms et al. ${ }^{44}(2015)$ 2010 consumption of food products that appeared on television was measured: Out of 120 students, 30 reported consuming 24 to 27 products, 23 students 21 to 23 products and 19 students 18 to 20 products. A positive association was found between unhealthy foods advertised on television and their consumption.

Children watched between 5 and 7 hours of television per day and more during weekends

Focus groups showed that children recalled several television advertisements and request items advertised on television, especially toys and foods.

Most boys and some girls were aware of the persuasive intentions of the advertisements.

Foods and beverage advertisements accounted for $35.4 \%$ of all product advertisements in all channels. According to the food classification scheme, $69.8 \%$ of foods were unhealthy. Most of the advertisements for unhealthy foods were childoriented $(92.1 \%)$.

In contrast to cable television channels, the public broadcast station did not air food advertisements aimed at children or marketing of unhealthy foods.

The study included 37 children, who reported choosing foods based primarily on taste preference but also for its variety, large quantity and low price. Children perceived products with fruits and vegetables on the packaging to be healthy and some would not consume them. Children had literal interpretations of images and packaging, such as that Cheetos were made from cheese and Grape Soda from grapes.

Researchers found that children influence the food purchased in their houses and have the economic autonomy to make their own food purchases. Sensory appeal, taste and sight were the main motivations for their choices. Another stimulus reported was the television, both advertisements and food appearing in television programs. Energydense and nutrient-poor foods were associated with leisure activities such as going to the movies.

It was observed that $23 \%$ of advertisements were for food products. Out of these, 56\% aired during children's programming and $43.7 \%$ aired during general audience programming.

Most foods and beverages advertised on children's programming had high levels of sugar $(69 \%)$ and sodium (56\%) and medium to high levels of total fat $(57.8 \%)$ and saturated fat $(63.3 \%)$. None of the food products advertised during this programming were significant sources of fiber.

In general programming, most foods and beverages were high in total fat $(70.4 \%)$, and sodium (44\%).

In total, 100 advertisements were recorded, 53 from rural areas and 47 from urban areas. The most frequent themes of advertisements were:

"cheap price, large size and fast" found in more in rural than in urban advertisements, followed by "modern" also found in both but more in urban and then "refreshing" found in both settings. of methods and themes used by the advertisements and how it differs between rural and urban setting in $\mathrm{El}$ Salvador. documentation of billboard and wall advertisements of foods was conducted. Field notes were collected during one week. Researchers identified patterns and explored the themes, topics and symbols revealed in the advertisements. 
Table 1. Studies conducted in Latin-American countries about food marketing and health. Continuation

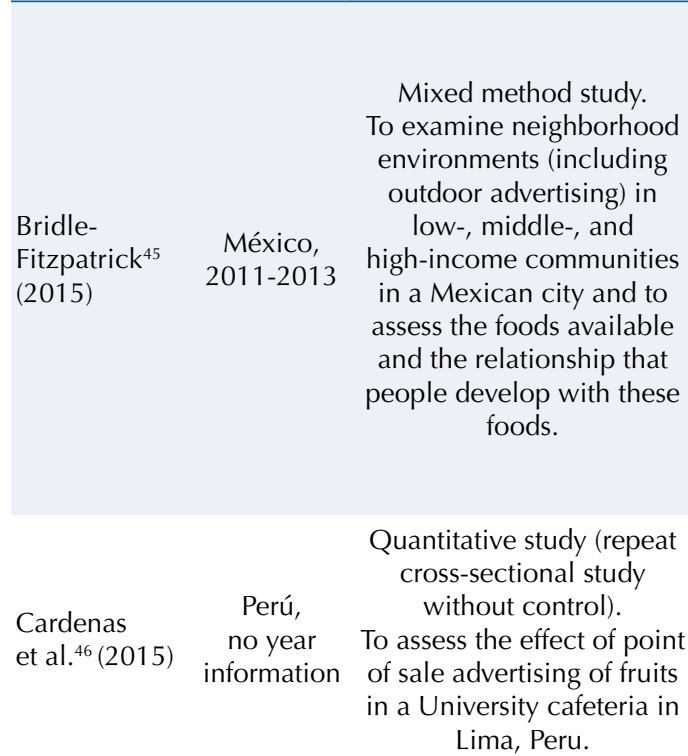

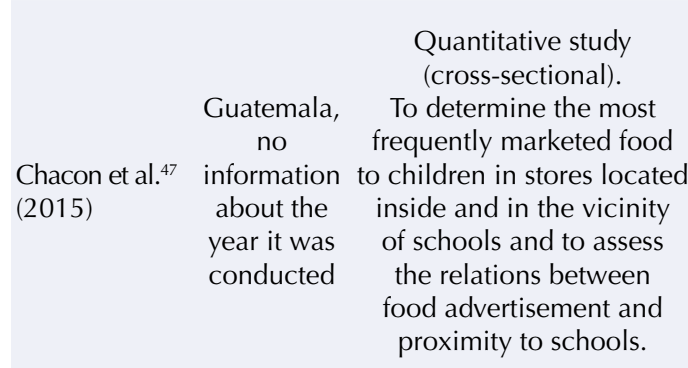

$\begin{array}{lc}\text { Ortiz-Pérez } & \text { Mexico, } \\ \text { et al. }{ }^{48}(2015) & 2012\end{array}$

Quantitative study

(cross-sectional).

To characterize the

nutritional profile of processed foods advertised on Channel 5 of Mexican television.

Quantitative study

To study the marketing

Soo et al. ${ }^{49} \quad$ Guatemala strategies used to advertise

(2016) breakfast cereals in

Guatemala and to examine

associations between

several marketing strategies

and nutritional quality. (cross-sectional).

Three schools representing communities of low, middle, and high socioeconomic status were selected in the city of Mazatlán during 20112013. Neighborhood food environments were assessed delineating three urban areas of approximately $1.5 \mathrm{~km}^{2}$ that included schools and streets. Observational tools were used to assess the quantity, prices and promotion strategies of food and beverages products commonly consumed.

Fruits were moved closer to the register desk, their price decreased, and signs were displayed to advertise their purchase.

Four public schools (two preschools and two primary institutions) were selected in the city of Mixco, Guatemala. Food stores located inside and within a 200-meter radius from these schools were surveyed to assess the number and type of foods and beverages advertised to children.

Channel 5 was recorded during children's programming hours for a week. Food advertisements were analyzed for duration and advertising strategy and the nutritional content was obtained from food packaging.

All available breakfast cereals in Guatemala City were included in this study. A content analysis was performed to document child-oriented marketing, product claims, and health-evoking images. The Nutrient Profile Model (NPM) was used to calculate an overall nutrition score for each cereal (the higher the score, the lower the nutritional quality).

Images of tobacco, alcohol and food advertisements were found on Brazilian web pages and analyzed in terms of color

Mixed method study. To compare the content Viacava et al. ${ }^{50} \quad$ Brazil, of advertisements used by (2016) no year information alcohol, tobacco and food industries and to study similarities in strategy.
Lower-income and lower-middle-income families resided in areas with a greater number of traditional stores that gave them access to sweetened beverages and salty snacks. Upper-middle- and high-income areas have more large-scale supermarkets and fast food restaurants but less overall access to sweetened beverages and snacks.

Almost all participants who resided in low-

and middle-income areas included, in their

photographic documentation, marketing strategies of different types for soft drinks and snack products. In high-income areas, only one student documented this kind of marketing.

Fruit sales showed a statistically significant increase between the initial state and the final stage of the study.

One third of food advertisements were childoriented (29\%). Stores located closer to schools had more display racks and shelves promoting child-oriented snack foods compared with those

further away. The main items advertised were sweetened beverages (37\%) and soft drinks (30\%).

Food advertisements represented $36.4 \%$ of all advertisements. All foods displayed were processed foods with high levels of sugars and carbohydrates (74\%), fats and sodium (17.5\%), and milk products high in sugar $(8.5 \%)$. No advertisements were found for unprocessed foods. The most advertised food group was sweetened cereals and was advertised using cartoons and had adventure and fun themes

In total, 106 breakfast cereals were analyzed and half $(50.9 \%)$ of them were child-oriented. The most common marketing strategy was the use of spokes-characters. More than half of the cereals $(88.7 \%)$ contained a product claim on the package front such as "nutritious" and "whole grain" and almost all cereals (96.2\%) had health evoking imagery. Child-oriented cereals had higher sugar content $(10.1 \mathrm{~g}$ versus $6.19 \mathrm{~g} / 30 \mathrm{~g}$ ) compared with non-child-oriented cereals. Cereals with health or nutrition claims were not significantly healthier than those without claims.

A total of 150 images were studied. Both the tobacco and alcohol industries use the color blue, whereas food advertisements use mostly red and green colors. These colors probably promote hunger and alter the perception that consumers have of the nutritional value of the product. More than half of the advertisements had the product name and brand occupying 0-25\% of the advertising image (46\%), followed by cartoons $(17.3 \%)$ and celebrities $(16.7 \%)$. The use of cartoons was most prevalent in the food products. More than half of the advertisements also used product appeal such as flavor, quality, and innovation. Another theme found was emotional appeal with themes such as physical attraction, happiness and sports.

The nutritional assessment found that $82 \%$ of the foods advertised were unhealthy.
Fair

quality

Good quality 
Table 1. Studies conducted in Latin-American countries about food marketing and health. Continuation

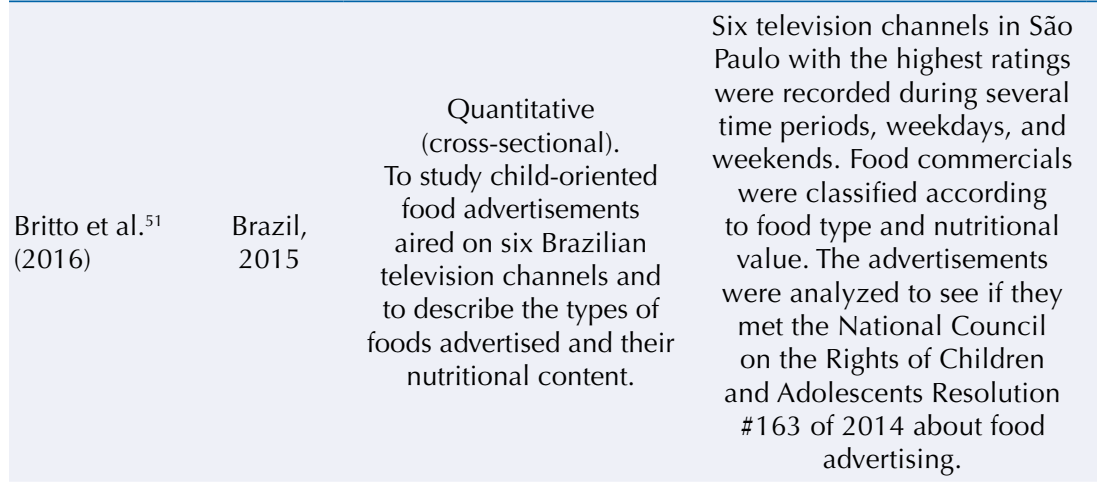

Quantitative

(cross-sectional).

To study and to describe the

Busse. ${ }^{52}$

Peru,

food advertisements that

(2016) 2002-2013 pear in child-oriented television programs in Peru and to study their effects on eating behaviors.

\begin{tabular}{|c|c|c|}
\hline $\begin{array}{l}\text { Castronuovo } \\
\text { et al. }{ }^{53}(2016)\end{array}$ & $\begin{array}{c}\text { Argentina, } \\
2015\end{array}$ & $\begin{array}{c}\text { Quantitative } \\
\text { (cross-sectional). } \\
\text { To analyze how mothers } \\
\text { from Buenos Aires with } \\
\text { different socioeconomic } \\
\text { levels perceive food } \\
\text { advertisements. }\end{array}$ \\
\hline
\end{tabular}

\section{Quantitative}

(cross-sectional).

To describe and assess

the use of toys and price

Mazariegos Guatemala, incentives in fast food

et al. ${ }^{54}$ (2016) $\quad \begin{gathered}\text { no year } \\ \text { information chain restaurants in }\end{gathered}$

Guatemala and to explore the nutritional quality of children's combo-meals with health claims.

\section{Quantitative \\ (cross-sectional). \\ To assess the nutritional quality of foods advertised on Mexican television \\ Patiño et al. ${ }^{55}$ Mexico, according to the Mexican (2016) 2012-2013 nutritional standards, \\ World Health Organization standards and the European and United Kingdom \\ Nutrient Profiling Model} (UKNPM).
Twenty-five television to be children's favorite, were recorded over a period of two weeks at three separate times of the year: spring, summer and winter.

Eight focus groups were conducted with the participation of 49 mothers with different education levels and who had children between the ages of 5 and 13. A questionnaire was conducted in the focus groups aiming to discuss the importance of food advertising at the moment of making decisions about their children's diet and health.

Children's combo-meals from all major fast food chains in Guatemala were purchased and their marketing strategies were analyzed. Nutritional profiles were assessed based on the UK Nutrient Profiling Model.

Four broadcast stations with the highest national ratings were recorded, including broadcast for several audiences and types of programs. Advertisements were classified and the nutritional profiles of the food items were obtained. Three nutritional models were used to assess the nutritional quality of the food items. programs, previously found (cross-sectional). information To assess child-oriented

Théodore et al. $^{56}(2016)$ about the year it was conducted television advertisements by companies who have signed self-regulation agreements.
Food and nonalcoholic beverage advertisements accounted for $5.6 \%$ of the advertisements. The most advertised foods on all six television channels were ultra-processed foods. Candy and packaged snacks were only advertised on one channel. Most of the food commercials $(64.3 \%)$ used children's language and characters; $43 \%$ used songs in children's voices, and $21.4 \%$ used premium offers, against the National Council on the Rights of Children and Adolescents.

Among the total number of advertisements recorded, $16.73 \%$ were food and beverage advertisements. In television programs, 28.3\% included food items. Sweets and sweetened nonalcoholic beverages accounted for $47.6 \%$

of food and beverage advertisements. No advertisements aired fruits and vegetables. The most frequent marketing technique observed was the use of words to heighten the sensory appeal of foods $(33 \%)$, followed by novelty $(27 \%)$.

Researchers found children influence the purchasing decisions of their mothers, and mothers perceive that television advertising by spokescharacters and premium offers impel children to crave certain foods and beverages. Mothers also reported being impelled to buy certain food for their children based on nutritional or health claims. Mothers said that both them and their children were susceptible to brand loyalty.

In total, 114 children's combo-meals were found with a frequency of $9.5 \%$ to $25 \%$ per fast food restaurant. All these combo-meals included according to the NPM even though three of these UKNPM standards. During cartoon programming with the highest national ratings were recorded and the commercials were classified and analyzed. a toy giveaway. Nutritional information was only available for 2 of the 6 restaurants. All the children's combo meals were "less healthy" meals had health claims.

Food and nonalcoholic beverage advertisements represented $20.7 \%$ of all advertisements recorded. Those that aired during cartoon programs had the highest energy and sugar content and had the lowest nutritional quality when compared with other types of programming. More than $60 \%$ of foods advertised did not meet any standard nutrient profile model; $64.3 \%$ did not meet the Mexican nutritional standards, $83.1 \%$ did not meet the WHO standards and $78.7 \%$ did not meet only $33.9 \%, 8.6 \%$ and $17.2 \%$ of the foods complied with the Mexican, WHO Europe and UKNPM standards, respectively.

More than half $(74.9 \%)$ of all advertisements tried to influence children's purchases and consumption. Companies that signed selfregulation agreements and those that did not sign advertised mainly unhealthy foods and

Good quality beverages. Companies that signed self-regulation agreements had less advertisements directly aimed at children. 
Table 1. Studies conducted in Latin-American countries about food marketing and health. Continuation

\begin{tabular}{|c|c|c|c|c|c|}
\hline $\begin{array}{l}\text { Zucchi et al. }{ }^{57} \\
(2016)\end{array}$ & $\begin{array}{c}\text { Brazil, } \\
\text { no year } \\
\text { information }\end{array}$ & $\begin{array}{l}\text { Mixed methods study. } \\
\text { To study and describe the } \\
\text { nutrient claims printed on } \\
\text { food packaging of child- } \\
\text { oriented ultra-processed } \\
\text { foods and explore } \\
\text { children's understanding of } \\
\text { these marketing strategies. }\end{array}$ & $\begin{array}{l}\text { A supermarket belonging } \\
\text { to one of the largest } \\
\text { supermarket chains in } \\
\text { Brazil was chosen for this } \\
\text { study. Packaged foods were } \\
\text { identified and classified } \\
\text { according to their target } \\
\text { audience. Nutritional } \\
\text { information available on } \\
\text { the packaging was used } \\
\text { to determine which foods } \\
\text { were ultra-processed. These } \\
\text { ultra-processed foods were } \\
\text { then classified according to } \\
\text { their nutrient claims. Focus } \\
\text { groups were conducted } \\
\text { with children between } 8 \\
\text { to } 10 \text { years old to explore } \\
\text { their perception of package } \\
\text { advertising on ultra- } \\
\text { processed foods. }\end{array}$ & $\begin{array}{l}\text { The researchers identified } 535 \text { packaged foods } \\
\text { that were child-oriented. Among these, } 472 \text { or } \\
88 \% \text { were classified as ultra-processed foods. } \\
\text { Within this group of ultra-processed foods, } 46.6 \% \\
\text { had at least one nutrient claim on the packaging } \\
\text { front. The most common nutrient claims were } \\
\text { the presence of vitamins and minerals followed } \\
\text { by reduction claims regarding trans fats. Nine } \\
\text { focus groups were carried out with } 49 \text { children. } \\
\text { They showed interest in spokes-characters and } \\
\text { reported liking the fact that foods were marketed } \\
\text { directly at them as an age group. They considered } \\
\text { nutrient claims were directed at parents. Their } \\
\text { interpretation of health claims was considered a } \\
\text { positive characteristic of the food product. }\end{array}$ & $\begin{array}{c}\text { Fair } \\
\text { quality }\end{array}$ \\
\hline $\begin{array}{l}\text { Rovirosa et al. }{ }^{58} \\
(2017)\end{array}$ & $\begin{array}{c}\text { Argentina } \\
\text { 2013-2014 }\end{array}$ & $\begin{array}{l}\text { Quantitative } \\
\text { (cross-sectional). } \\
\text { To study and describe the } \\
\text { frequency and duration } \\
\text { of food and beverage } \\
\text { advertisements aired during } \\
\text { children's programming, } \\
\text { and the nutritional quality } \\
\text { of these foods. }\end{array}$ & $\begin{array}{l}\text { Children's programming aired } \\
\text { in the city of Buenos Aires was } \\
\text { recorded during weekdays } \\
\text { and weekends. Television } \\
\text { advertisements were analyzed, } \\
\text { and the nutritional data of the } \\
\text { products was assessed using } \\
\text { the Nutrient Profiling Model } \\
\text { and the traffic light labeling } \\
\text { system. }\end{array}$ & $\begin{array}{l}\text { Food and beverage advertisements represented } \\
20.9 \% \text { of the television advertisements recorded. } \\
\text { Dairy products, candies, and fast-food meals were } \\
\text { the most advertised food products. According } \\
\text { to the Nutrient Profiling Model only a third of } \\
\text { advertised foods and beverages were healthy. } \\
\text { Based on the traffic light labeling system almost } \\
\text { half of the food products was high in sugar, a } \\
\text { quarter was high in saturated fats, and } 15 \% \text { was } \\
\text { high in sodium and total fats. }\end{array}$ & $\begin{array}{c}\text { Fair } \\
\text { quality }\end{array}$ \\
\hline $\begin{array}{l}\text { Allemandi } \\
\text { et al. }{ }^{59}(2017)\end{array}$ & $\begin{array}{c}\text { Argentina } \\
\text { 2013-2014 }\end{array}$ & $\begin{array}{c}\text { Quantitative } \\
\text { (cross-sectional). } \\
\text { To characterize the } \\
\text { television advertisements } \\
\text { of ultra-processed foods } \\
\text { targeted to children. }\end{array}$ & $\begin{array}{l}\text { The three most popular } \\
\text { cable channels targeted at } \\
\text { children and five broadcast } \\
\text { channels were recorded for } 6 \\
\text { weeks. Foods were classified } \\
\text { following the NOVA system. } \\
\text { PAHO nutrient profile model } \\
\text { was used to assess the } \\
\text { nutritional quality. }\end{array}$ & $\begin{array}{l}\text { Ultra-processed foods were advertised the most } \\
\text { during programs aimed at children }(98.9 \%), \\
\text { compared with programs targeted towards general } \\
\text { audience (93.7). }\end{array}$ & $\begin{array}{c}\text { Good } \\
\text { quality }\end{array}$ \\
\hline
\end{tabular}

Several studies also found that more food advertisements appear during children's programming compared with general audience programming and that child-oriented advertisements had less nutritional quality compared with general audience advertisements ${ }^{24,28,40,43,52,56,57}$.

Ten studies found most children enjoyed television food advertisements and are enticed by these ads to try new foods ${ }^{25,26,30,32-34,38,39,42,54}$.

A Mexican study assessed the self-regulation agreement implemented by the industry in that country in 2012. The authors found that $93 \%$ of the advertisements, from companies that had signed the self-regulation agreements, promoted unhealthy food and beverages ${ }^{57}$.

Three studies found the most common marketing technique used on food packages was licensed characters - especially in child-oriented products - followed by the presence of health claims ${ }^{35,50,58}$.

A Guatemalan study found children had a literal interpretation of food packaging, which leads to a misunderstanding about the nutritional value and the ingredients of products; children believe, for example, that the food drawn on the packaging represents the ingredient of the product inside. ${ }^{41}$ Another study, which assessed snack foods available in stores near schools, found that almost all child-oriented products were considered unhealthy according to the UK Food Agency standards..$^{35} \mathrm{~A}$ third study, which gathered breakfast cereals available in supermarkets in Guatemala City, observed cereals marketed to children had higher sugar content compared with cereals marketed to other age groups. ${ }^{50}$ 

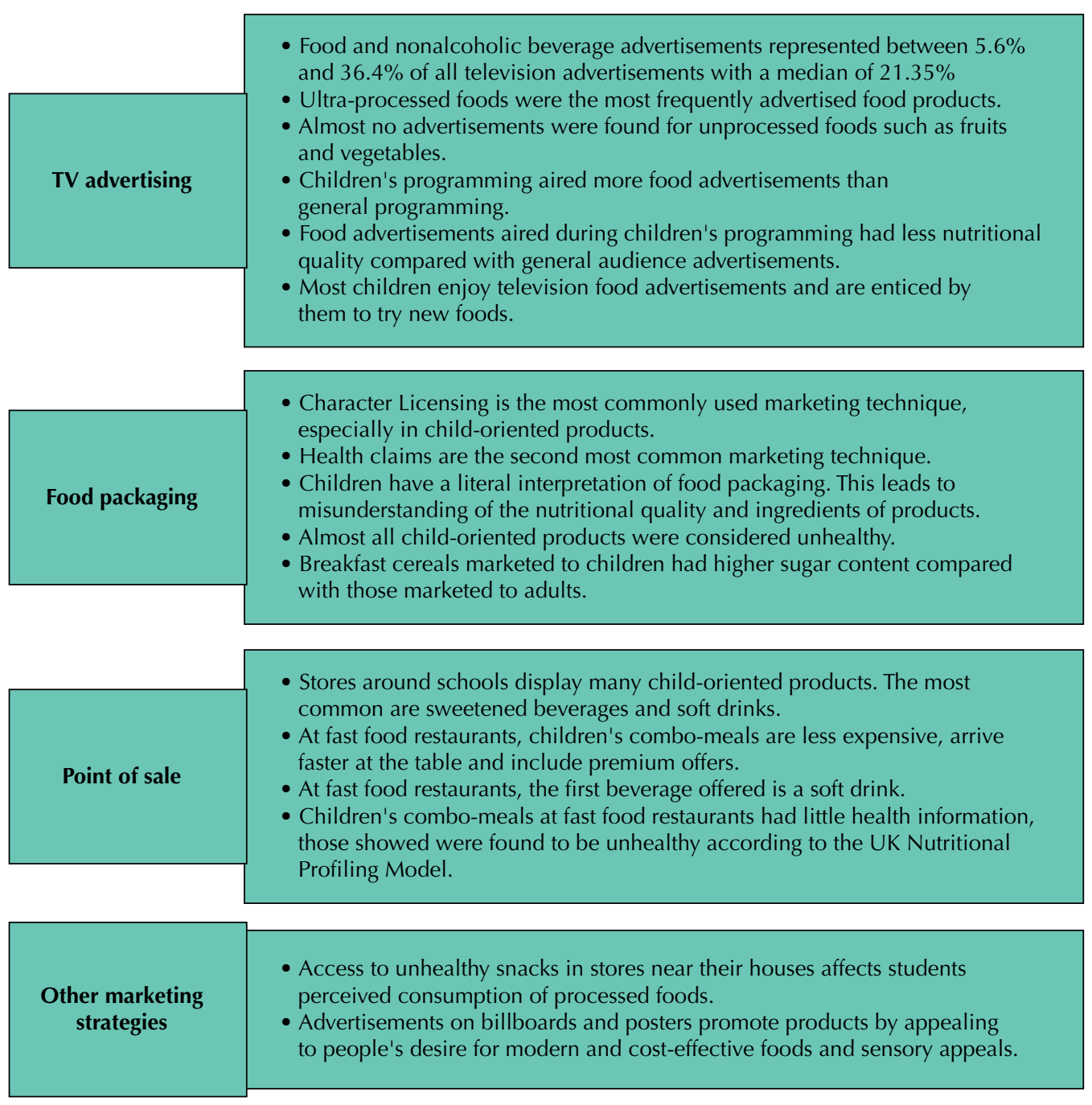

Figure 2. Main findings based on marketing typology.

Another study conducted in Guatemala analyzed the point of sale marketing strategies in stores located around schools to determine the relation between food advertising and proximity to schools. This study found many child-oriented products with a proportional relation between them and the distance to the school. The most common products found were sweetened beverages and soft drinks ${ }^{48}$.

Also in Guatemala, a study exploring point of sale marketing in fast food restaurants observed that only five children's combo meals out of 19 had nutrition information, and all of them were classified as "less healthy" according to the UK Nutrient Profiling Model. On average, combo meals were less expensive than children's meal items individually. All restaurants offered a soft drink as the first drink option and all combo meals included a toy giveaway ${ }^{55}$.

Advertisements on billboards and posters promote products by appealing to people's desire for modern and cost-effective foods vs traditional foods ${ }^{45}$.

Access to unhealthy snacks in stores near students' houses affects their perceptions of consumption of processed foods. Students who were asked to record the food they had access to, observing that, if unhealthy foods were available, they felt tempted to consume them ${ }^{46}$.

\section{DISCUSSION}

This scoping review synthesizes the evidence about the marketing of foods and beverages in Latin American countries in the last 15 years and provides insights about the challenges 
this issue represents to global and public health. This study also shows the different ways in which marketing companies interact with children when promoting ultra-processed foods and beverages in this region. Finally, it allows the identification of knowledge gaps that can guide the future research agenda in this area.

The main findings of this review can be described as follows: a) most foods and beverages advertised in television are ultra-processed foods and have low nutritional value $^{24,27,29,31,34,36-38,40,43,49,52,53,56,57,59}$; b) children's television programming contains several food advertisements and many studies found advertisements for this demographic group had a lower nutritional value compared with general audience programming ${ }^{24,28,40,43,52,56,57}$; c) food packages can be deceiving especially to children who have a literal interpretation of what is printed on the packaging ${ }^{35,50,58}$; d) proximity to unhealthy foods may increase the consumption of these foods $\mathrm{s}^{25,26,30,32,34,38,42,44,46,54}$. These findings enhance the necessity of implementing statutory policies covering all marketing channels and robust nutritional standards as the case of the Chilean regulations approved in $2012^{60}$. Similarly, the Brazilian food dietary guidelines and the Uruguayan food guidelines emphasized on encouraging and increasing consumption of natural and minimally processed foods while making recommendations for marketing ${ }^{61,62}$.

Television is one of the main channels used to advertise food products ${ }^{63}$ and more than half of the 37 studies included in this review focused on television advertising. The frequency of food advertisements was between $5.6 \%$ and $36.4 \%$ with a median of $21.35 \%^{24,27-}$ $29,34,36,37,40,43,49,52,53,56$. These results agree with those found by other studies worldwide. In the United States, a study by Powell et al $^{64}$ found $36.4 \%$ of television advertising corresponded to food promotions, a study also by Powell ${ }^{65}$ comparing television food advertisements seen by children in 2003 and 2007 saw a slight reduction from 13.1\%-13.6\% of ads watched by children in 2003 to $11.5 \%-13.6 \%$ in 2007. In the United Kingdom, Whalen et al. ${ }^{66}$ studied food promotions aired on television after statutory restrictions; food and drink ads were the third most advertised product with a frequency of $11.9 \%$. In China, a recent study by Danyong et al. ${ }^{67}$ reports that food advertisements constitute $25.5 \%$ of television ads and in a comparative study conducted in 2010 by research groups in Australia, Asia, Europe, North America and South America, food items represented 18\% of all television advertisements and represented the second most advertised product ${ }^{17}$.

The most frequently advertised foods on television were ultra-processed foods and sweetened beverages, with few advertisements for healthier options such as fruits and vegetables $24,27,29,31,34,36-38,40,43,49,52,53,56,57,59$. Researchers in developed countries have been repeatedly making this observation ${ }^{65,68}$. For example, in 2007, Powel et al ${ }^{69}$ found almost all food products advertised to children and adolescents in US television were high in fat, sugar or sodium. Another study also conducted in the US observed foods advertised on television contained in general too much sugar, fat and protein and too few servings of dairy, fruits and vegetables ${ }^{70}$.

Several of the studies included in this review also observed that children were heavily targeted by marketing and that foods marketed to them had a lower nutritional value compared with food advertised to adults ${ }^{24,28,40,43,52,56,57}$. In 2008 , WHO published a review of the evidence regarding food marketing to children, including 14 studies that compared television advertising to both populations, which found a larger proportion of food advertisements for children vs. adults ${ }^{63}$.

This is especially troubling since children's exposure to marketing of unhealthy foods has been connected to an increased energy intake and childhood obesity ${ }^{71,72}$. Latin America is experiencing a rapid increase in obesity and other associated non-communicable diseases in children and young adults ${ }^{73}$, and in 2014 a systematic review by Rivera et al. found that from 20 to $25 \%$ of the population were already obese ${ }^{74}$. We still have no knowledge of a study that analyzes the relation between television food advertising and childhood obesity rates in Latin America. According to a recent international comparison, the 
magnitude of the television advertising effect on overweight and obesity in children varies by country ${ }^{75}$, highlighting the necessity for evidence-based studies in Latin America illustrating this effect.

While numerous studies have focused on the nature of the food advertised on television, little can be said about the nature of other above-the-line advertising such as printed media. We found only one study that investigated advertisements printed on billboards, which were found to be all for fast food chains ${ }^{45}$.

This review did not find studies about the use of digital marketing. Adults and children across the world have increasing access to digital media, especially with the widespread availability of cellphones and, as such, digital marketing is becoming more significant ${ }^{76,77}$; it allows brands to emit widely amplifying advertising messages, achieving high levels of recall and brand awareness ${ }^{77}$. Additionally, digital marketing benefits from the personal information collected about the user and how this fact might affect consumers is still unknown. Latin America is a growing market for digital advertising with more than half of its population connected to the Internet, and as of 2015, it is the fourth largest mobile device market in the world ${ }^{78}$. As youth become increasingly and permanently connected through mobile media, new research in this region is needed to understand the prevalence and effects of digital marketing on children's health and consumption behaviors.

Below-the-line promotional techniques such as product packaging and product placement inside stores, as well as sponsorship of food items in movies or television programs, toy giveaways, free samples, and loyalty programs are also under-researched. We found nine studies that focused on food packaging and point of sale advertising. The results are similar to those of television advertising with most of the child-oriented products being ultra-processed foods and sweetened beverages. Studies found that children have a literal interpretation of food packaging and tend to believe the images and health claims printed on the packages ${ }^{41,50}$. Children also reported that easy access to unhealthy foods such as having stores inside and around schools and in the vicinity of their houses affected their consumption ${ }^{46}$. These findings place children in a particularly vulnerable situation when confronting purchasing decisions made with pocket money and are the development to an unhealthy diet in adult life.

Therefore, new research examining the effects of external factors (amplifying and attenuating) such as school environment, family communication styles and parental advertising mediation is needed. Family communication styles and parental advertising mediation has been found to moderate the effect of television ads geared towards children ${ }^{79}$, including food television advertising ${ }^{80}$. Other studies have analyzed how cognitive development and other psychological factors help children cope with advertising messages. Findings in these studies suggest children's executive function and advertising literacy directly affect children's consumer behavior when exposed to advertising ${ }^{81,82}$ and can help to moderate the effect.

Several limitations can be identified in this review. Firstly, despite the exhaustive search used in this review, we have the probability of having excluded thesis or dissertations conducted in the area that were not published in indexed journals. Secondly, we did not find studies conducted in countries such as Venezuela, Bolivia, Paraguay, and Panama, which limits the reach of conclusions of this review. Thirdly, the exploratory scope of this review does not enable conclusions and recommendations about specific topics of food marketing to be made. In consequence, this study should be considered as a preliminary approximation to this topic.

Despite these limitations, the results of this study may provide insights to guide policy actions to prevent the growing public health problem of obesity and non-communicable diseases. Furthermore, it can contribute to identifying knowledge gaps to lead the future research agenda in the area. 


\section{CONCLUSIONS}

This review synthesizes the evidence published in the last 15 years on marketing of food and beverages in Latin American countries. The main advertising medium explored by these studies was television advertising, and while studies focusing on digital advertising were not found, it is also gaining strength, especially among youths. These media transcend national borders and, as such, it is necessary to view the panorama of the region as a whole. This review provides insights about the challenges unhealthy eating represents to the public health of Latin America and identifies knowledge gaps to guide future research.

\section{REFERENCES}

1. University of Washington, Institute for Health Metrics and Evaluation. Global Burden of Disease Study. Seattle: IHME; 2017 [cited 2018 April 17]. Available from:

2. Te Morenga L, Mallard S, Mann J. Dietary sugars and body weight: systematic review and meta-analyses of randomised controlled trials and cohort studies. BMJ. 2013;346:e7492. https://doi.org/10.1136/bmj.e7492

3. Canella S, Levy RB, Martins APB, Claro RM, Moubarac JC, Baraldi LG, et al. Ultra-processed food products and obesity in Brazilian households (2008-2009). PLoS One. 2014;9(3):e92752. https://doi.org/10.1371/journal.pone.0092752

4. Imamura F, O'Connor L, Ye Z, Mursu J, Hayashino Y, Bhupathiraju SN, et al.

5. Monteiro CA, Levy RB, Claro RM, Castro IR, Cannon G. Increasing consumption of ultraprocessed foods and likely impact on human health: evidence from Brazil. Public Health Nutr. 2010;14(1):5-13. https://doi.org/10.1017/S1368980010003241

6. Martins APB, Levy RB, Claro RM, Moubarac JC, Monteiro CA. Increased contribution of ultraprocessed food products in the Brazilian diet (1987-2009). Rev Saude Publica. 2013;47(4):65665. https://doi.org/10.1590/S0034-8910.2013047004968

7. Rivera JA, Barquera S, González-Cossío T, Olaiz G, Sepúlveda J. Nutrition transition in Mexico and in other Latin American countries. Nutr Rev. 2004;62 Suppl 2:S149-57.

8. Harris JL, Pomeranz JL, Lobstein T, Brownell KD. A crisis in the marketplace: how food marketing contributes to childhood obesity and what can be done. Annu Rev Public Health. 2009;30:211-25. https://doi.org/10.1146/annurev.publhealth.031308.100304

9. Harris JL, Brownell KD, Bargh JA. The food marketing defense model: integrating psychological research to protect youth and inform public policy. Soc Issues Policy Rev. 2009;3(1):211-71. https://doi.org/10.1111/j.1751-2409.2009.01015.x

10. Cairns G, Angus K, Hastings G, Caraher M. Systematic reviews of the evidence on the nature, extent and effects of food marketing to children. A retrospective summary. Appetite. 2013;62:209-15. https://doi.org/10.1016/j.appet.2012.04.017

11. Palmer E, Carpenter C. Food and beverage marketing to children and youth: trends and issues. Media Psychol. 2006;8(2):165-90.

12. McGinnis JM, Gootman JA, Kraak VI, editors. Food marketing to children and youth: threat or opportunity? Washington, DC: National Academies Press; 2006

13. Lobstein T, Jackson-Leach R, Moodie ML, Hall KD, Gortmaker SL, Swinburn BA, et al. Child and adolescent obesity: part of a bigger picture. Lancet. 2015;385(9986):2510-20. https://doi.org/10.1016/S0140-6736(14)61746-3

14. Boyland EJ, Whalen R. Food advertising to children and its effects on diet: review of recent prevalence and impact data. Pediatr Diabetes. 2015;16(5):331-7. https://doi.org/10.1111/pedi.12278

15. Story $M$, French $S$. Food advertising and marketing directed at children and adolescents in the US. Int J Behav Nutr Phys Act. 2004;1(1):3. https://doi.org/

16. Singh AS, Mulder C, Twisk JW, Mechelen W, Chinapaw MJ. Tracking of childhood overweight into adulthood: a systematic review of the literature. Obes Rev. 2008;9(5):474-88. https://doi.org/10.1111/j.1467-789X.2008.00475.x

17. Peters MDJ, Godfrey CM, Mclnerney P, Soares CB, Khalil H, Parker D. TheJoanna Briggs Institute reviewers' manual 2015: methodology for JBI Sscoping reviews. Adelaide (AUS): The Joanna Briggs Institute; 2015. 
18. Colquhoun HL, Levac D, O’Brien KK, Straus S, Tricco AC, Perrier L, et al. Scoping reviews: time for clarity in definition, methods, and reporting. J Clin Epidemiol. 2014;67(12):1291-4. https://doi.org/10.1016/j.jclinepi.2014.03.013

19. PRISMA - Preferred Reporting Items for Systematic Reviews and Meta-Analyses. Ottawa (CAN); 2015 [cited 2018 April 10]. Available from: http://www.prisma-statement.org/

20. World Health Organization. A framework for implementing the set of recommendations on the marketing of foods and non-alcoholic beverages to children. Geneva: WHO; 2012.

21. Sonntag D, Schneider S, Mdege N, Ali S, Schmidt B. Beyond food promotion: a systematic review on the influence of the food industry on obesity-related dietary behaviour among children. Nutrients. 2015;7(10):8565-76. https://doi.org/10.3390/nu7105414

22. Braun V, Clarke V. Using thematic analysis in psychology. Qual Res Psychol. 2006;3(2):77-101.

23. Almeida SS, Nascimento PCBD, Quaioti TCB. [Amount and quality of food advertisement on Brazilian television]. Rev Saude Publica. 2002;36(3):353-5. Portuguese.

24. Olivares S, Yáñez R, Díaz N. Publicidad de alimentos y conductas alimentarias en escolares de $5^{\circ}$ a $8^{\circ}$ básico. Rev Chil Nutr. 2003;30(1):36-42.

25. Fiates GMR, Amboni RDMC, Teixeira E. Television use and food choices of children: qualitative approach. Appetite. 2008;50(1):12-8

26. Ramírez-Ley K, De Lira-García C, Souto-Gallardo ML, Tejeda-López MF, Castañeda-González LM, Bacardí-Gascón M, et al. Food-related advertising geared toward Mexican children. J Public Health (Oxf). 2009;31(3):383-8. https://doi.org/10.1093/pubmed/fdp058

27. Pérez-Salgado D, Rivera-Márquez JA, Ortiz-Hernández L. Publicidad de alimentos en la programación de la televisión mexicana: ¿los niños están más expuestos? Salud Publica Mex. 2010;52(2):119-26. https://doi.org/10.1590/S0036-36342010000200003

28. Crovetto-M M, Durán-T M, Guzmán-R M, Miranda-H C. Estudio descriptivo de la frecuencia y duración de la publicidad alimentaria emitida en la programación de canales de televisión asociados a ANATEL. Rev Chil Nutr. 2011;38(3):290-9.

29. Olivares-C S, Lera-M L, Mardones-H MA, Araneda-F J, Bustos-Z N, Olivares-C MA, et al. Promoción de alimentos y preferencias alimentarias en escolares chilenos de diferente nivel socioeconómico. Arch Latinoam Nutr. 2011;61(2):163-71.

30. Santos CC, Stuchi RAG, Arreguy-Sena C, Pinto NAVD. [Television's influence on eating habits, practices and behavior]. Cogitare Enferm. 2012;17(1):65-71. Portuguese. $h$

31. Rodrigues VM, Fiates GMR. [Children's eating habits and consumer behavior: influence of household income and television viewing habits. Rev Nutr. 2012;25(3):353-62. Portuguese. https://doi.org/10.1590/S1415-52732012000300005

32. Costa SMM, Horta PM, Santos LC. Food advertising and television exposure: influence on eating behavior and nutritional status of children and adolescents. Arch Latinoam Nutr. 2012;62(1):53-9.

33. Bacardí-Gascón M, Díaz-Ramírez G, Cruz López B, López Zuñiga E, Jiménez-Cruz A. TV food advertisements' effect on food consumption and adiposity among women and children in México. Nutr Hosp. 2013;28(6):1900-4. https://doi.org;10.3305/nutr hosp.v28in06.6966

34. Chacon V, Letona P, Barnoya J. Child-oriented marketing techniques in snack food packages in Guatemala. BMC Public Health. 2013;13:967. https://doi.org/10.1186/1471-2458-13-967

35. Díaz-Ramírez G, Jiménez-Cruz A, Souto-Gallardo MC, Bacardí-Gascón M. Effect of the exposure to TV food advertisements on the consumption of foods by mothers and children. J Pediatr Gastroenterol Nutr. 2013;56(1):86-8. https://doi.org/10.1097/MPG.0b013e3182638d13

36. Costa SM, Horta PM, Santos LC. Analysis of television food advertising on children's programming on "free-to-air" broadcast stations in Brazil. Rev Bras Epidemiol. 2013;16(4):976-83.

37. Rojas-Huayllani EC, Delgado-Pérez DH. [Influence of Peruvian television advertising in unhealthy food consumption in 4th to 6th grade elementary scholars]. An Fac Med. 2013;74(1):21-26. Spanish

38. Busse P, Díaz R. What are the television viewing and eating habits of children in Peru? Glob Health Promot. 2016;23(1):50-60. https://doi.org/10.1177/1757975914547923

39. Gunderson MD, Clements D, Benjamin Neelon SE. Nutritional quality of foods marketed to children in Honduras. Appetite. 2014;73:1-6. https://doi.org/10.1016/j.appet.2013.10.009 
40. Letona P, Chacon V, Roberto C, Barnoya J. A qualitative study of children's snack food packaging perceptions and preferences. BMC Public Health. 2014;14:1274. https://doi.org/10.1186/1471-2458-14-1274

41. Mazzonetto AC, Fiates GMR. Perceptions and choices of Brazilian children as consumers of food products. Appetite. 2014;78:179-84. https://doi.org/10.1016/j.appet.2014.03.028

42. Mejía-Díaz D, Carmona Garcés IC, Giraldo-López P, González-Zapata L. Contenido nutricional de alimentos y bebidas publicitados en la franja infantil de la televisión colombiana. Nutr Hosp. 2014;29(4):858-64.

43. Amanzadeh B, Sokal-Gutierrez K, Barker JC. An interpretive study of food, snack and beverage advertisements in rural and urban El Salvador. BMC Public Health. 2015;15:521. https://doi.org/10.1186/s12889-015-1836-9

44. Bridle-Fitzpatrick S. Food deserts or food swamps? A mixed-methods study of local food environments in a Mexican city. Soc Sci Med. 2015;142:202-13. https://doi.org/10.1016/j.socscimed.2015.08.010

45. Cárdenas MK, Benziger CP, Pillay TD, Miranda JJ. The effect of changes in visibility and price on fruit purchasing at a university cafeteria in Lima, Peru. Public Health Nutr. 2015;18(15):2742-9. https://doi.org/10.1017/S1368980014002730

46. Chacon V, Letona P, Villamor E, Barnoya J. Snack food advertising in stores around public schools in Guatemala. Crit Public Health. 2015;25(3):291-8. https://doi.org/10.1080/09581596.2014.953035

47. Ortiz-Pérez H, Molina-Frechero N, Martínez-Barbabosa I, Córdova-Moreno R. Contenido nutricional de los alimentos promovidos por el Canal 5 de la televisión mexicana dirigidos a la población infantil. Rev Chil Nutr. 2015;42(3):260-6.

48. Soo J, Letona P, Chacon V, Barnoya J, Roberto CA. Nutritional quality and child-oriented marketing of breakfast cereals in Guatemala. Int J Obes (Lond). 2016;40(1):39-44. https://doi.org/10.1038/ijo.2015.161

49. Viacava KR, Weydmann GJ, Vasconcelos MF, Jaboinski J, Batista GD, Almeida RM, et al. It is pleasant and heavy: convergence of visual contents in tobacco, alcohol and food marketing in Brazil. Health Promot Int. 2016;31(3):674-83. https://doi.org/10.1093/heapro/dav057

50. Britto SR, Viebig RF, Morimoto JM. Analysis of food advertisements on cable television directed to children based on the food guide for the Brazilian population and current legislation. Rev Nutr. 2016;29(5):721-9.

51. Busse P. Food content of TV shows seen by children in Peru: a double dose of food messages? Int J Commun. 2016;10:1194-211.

52. Castronuovo L, Gutkowski P, Tiscornia V, Allemandi L. Las madres y la publicidad de alimentos dirigida a niños y niñas: percepciones y experiencias. Salud Colectiva. 2016;19;12(4):537-50.

53. Mazariegos S, Chacón V, Cole A, Barnoya J. Nutritional quality and marketing strategies of fast food children's combo meals in Guatemala. BMC Obesity. 2016;3:52.

54. Patiño SRG, Tolentino-Mayo L, Flores Monterrubio EA, Harris JL, Vandevijvere S, Rivera JA, et al. Nutritional quality of foods and non-alcoholic beverages advertised on Mexican television according to three nutrient profile models. BMC Public Health. 2016;16:733. https://doi.org/10.1186/s12889-016-3298-0

55. Théodore FL, Tolentino-Mayo L, Hernández-Zenil E, Bahena L, Velasco A, Popkin B, et al. Pitfalls of the self-regulation of advertisements directed at children on Mexican television. Pediatr Obes. 2017;12(4):312-9. https://doi.org/10.1111/ijpo.12144

56. Zucchi ND, Fiates GMR. Analysis of the presence of nutrient claims on labels of ultra-processed foods directed at children and of the perception of kids on such claims. Rev Nutri. 2016;29(6):821-32.

57. Rovirosa A, Zapata ME, Gómez P, Gotthelf S, Ferrante D. Food and beverage advertising on children's TV channels in Argentina: frequency, duration, and nutritional quality. Arch Argent Pediatr. 2017; 115(1):28-34. https://doi.org/10.5546/aap.2017.eng.28

58. Allemandi L, Castronuovo L, Tiscornia MV, Ponce M, Schoj V. Food advertising on Argentinean television: are ultra-processed foods in the lead? Public Health Nutr. 2018;21(1);238-46. https://doi.org/10.1017/S1368980017001446 
59. Corvalán C, Reyes M, Garmendia ML, Uauy R. Structural responses to the obesity and noncommunicable diseases epidemic: update on the Chilean law of food labelling and advertising. Obes Rev. 2019;20(3):367-74. https://doi.org/10.1111/obr.12802

60. Ministerio da Saúde (BR), Secretaría de Atenção à Saúde, Departamento de Atenção Básica. Guia alimentar para a população brasileira: relatório final da consulta pública. Brasília, DF; 2015 [cited 2018 April 17]. Available from:

61. Ministerio de Salud (URY). Guía alimentaria para la población uruguaya: para una alimentación saludable, compartida y placentera. Montevideo; 2016.

62. Cairns G, Angus K, Hastings G. The extent, nature and effects of food promotion to children: a review of the evidence to December 2008. Geneva: WHO; 2009?

63. Powell LM, Szczypka G, Chaloupka FJ. Exposure to food advertising on television among US children. Arch Pediatr Adolesc Med. 2007;161(6):553-60. https://doi.org/10.1001/archpedi.161.6.553

64. Powell LM, Szczypka G, Chaloupka FJ. Trends in exposure to television food advertisements among children and adolescents in the United States. Arch Pediatr Adolesc Med. 2010;164(9):794-802. https://doi.org/10.1001/archpediatrics.2010.139

65. Whalen R, Harrold J, Child S, Halford J, Boyland E. Children's exposure to food advertising: the impact of statutory restrictions. Health Promot Int. 2019;34 (2):227-35. https://doi.org/10.1093/heapro/dax044

66. Li D, Wang T, Cheng Y, Zhang M, Yang X, Zhu Z, et al. The extent and nature of television food advertising to children in Xi'an, China. BMC Public Health. 2016;16(1):770. https://doi.org/10.1186/s12889-016-3468-0

67. Boyland EJ, Harrold JA, Kirkham TC, Halford JCG. The extent of food advertising to children on UK television in 2008. Int J Pediatr Obes. 2011;6(5-6):455-61. https://doi.org/10.3109/17477166.2011.608801

68. Powell LM, Szczypka G, Chaloupka FJ, Braunschweig CL. Nutritional content of television food advertisements seen by children and adolescents in the United States. Pediatrics. 2007;120(3):576-83. https://doi.org/10.1542/peds.2006-3595

69. Mink M, Evans A, Moore CG, Calderon KS, Deger S. Nutritional imbalance endorsed by televised food advertisements. J Am Diet Assoc. 2010;110(6):904-10. https://doi.org/10.1016/j.jada.2010.03.020

70. Sadeghirad B, Duhaney T, Motaghipisheh S, Campbell NR, Johnston BC. Influence of unhealthy food and beverage marketing on children's dietary intake and preference: a systematic review and meta-analysis of randomized trials. Obes Rev. 2016;17(10):945-59. https://doi.org/10.1111/obr.12445

71. Andreyeva T, Kelly IR, Harris JL. Exposure to food advertising on television: associations with children's fast food and soft drink consumption and obesity. Econ Hum Biol. 2011;9(3):221-33. https://doi.org/10.1016/j.ehb.2011.02.004

72. Corvalán C, Garmendia ML, Jones-Smith J, Lutter CK, Miranda JJ, Pedraza LS, et al. Nutrition status of children in Latin America. Obes Rev. 2017;18 Suppl 2:7-18. https://doi.org/10.1111/obr.12571

73. Rivera JA, Cossio TG, Pedraza LS, Aburto TC, Sánchez TG, Martorell R. Childhood and adolescent overweight and obesity in Latin America: a systematic review. Lancet Diabetes Endocrinol. 2014;2(4):321-32.

74. Goris JM, Petersen S, Stamatakis E, Veerman JL Television food advertising and the prevalence of childhood overweight and obesity: a multicountry comparison. Public Health Nutr. 2010:13(7):1003-12. https://doi.org/10.1017/S1368980009992850

75. Weber K, Story M, Harnack L. Internet food marketing strategies aimed at children and adolescents: a content analysis of food and beverage brand websites. J Am Diet Assoc. 2006;106(9):1463-6.

76. World Health Organization, Regional Office for Europe. Tackling food marketing to children in a digital world: trans-disciplinary perspectives. Copenhagen (DNK); 2016.

77. Kelly N. How marketing is evolving in Latin America. Harvard Bus Rev. 2015 Jun 1 [cited 2018 April 17]. Available from:

78. Bruijzen M, Valkenburg PM. Parental mediation of undesired advertising effects. J Broadcast Electron Media. 2005;49(2):153-65. 
79. Buijzen M. The effectiveness of parental communication in modifying the relation between food advertising and children's consumption behaviour. Br J Dev Psychol. 2009;27(1):105-21.

80. Lapierre MA. Advertising literacy and executive function: testing their influence on children's consumer behavior. Media Psychol. 2019;22(1):35-59.

81. Livingstone S, Helsper EJ. Does advertising literacy mediate the effects of advertising on children? A critical examination of two linked research literatures in relation to obesity and food choice. J Commun. 2006;56(3):560-84.

Funding: This research was supported by Bloomberg Philanthropies (Subward number \# 5103721).

Acknowledgments: We thank Lindsey Smith Taillie and Barry Popkin for their support and leadership. We thank Yersika Caro y Maria Fernanda Carreño for their support in the data synthesis.

Author Contributions: Maria Manuela Chemas-Vélez and Luis F Gómez conceived the scope of the study, defined the conceptualization, developed the methodological approach, and led the writing of sections of the manuscript. Alcides Velasquez, Mercedes Mora-Plazas y Diana C Parra contributed to the interpretation of the results. All authors discussed the results and contributed to the final manuscript.

Conflict of Interest: The authors declare no conflict of interest. 